\title{
A Study on Middle School Students' Perceptions on Remote English Learning During COVID-19
}

\author{
Kong, Ji Eun'; Lee, Daeun²
}

\begin{abstract}
The world has experienced an unprecedented era for education being conducted online due to COVID-19. Thus, this study explored South Korea's middle school students' perception of emergent remote English learning (EREL) in terms of satisfaction, interest, self-directed learning, achievement, and interaction during the pandemic. Valid data from 263 participants were collected from the survey conducted in Seoul and Gyeonggi area. SPSS was used to conduct descriptive analysis, frequency analysis, and an independent sample $t$-test. This study's findings showed that participants are generally satisfied with EREL because of convenience, a sufficient amount of material covered, the possibility of self-paced learning, and a high level of interaction between teachers. Participants also revealed a high level of interest in EREL because of the contents provided through multimedia and added that they were able to enhance their abilities to use mobile devices through EREL. However, participants responded that EREL lowered their concentration in class due to the lack of interaction with their peers, decreasing their interest in the learning process. Thus, the quality of EREL must be enhanced for them to focus more on learning through carefully designed courses that include collaborative activities, interesting learning materials, and an appropriate assessment approach for EREL.
\end{abstract}

Keywords: perception of online learning, emergency remote language learning, COVID-19 Applicable level: secondary

\footnotetext{
${ }^{1}$ First author, Ph.D. Student, Department of British-American Literature \& Culture, Kyung Hee University, 1732, Deogyeongdaero, Giheung-gu, Yongin-si, Gyeonggi-do, 17104, Korea (E-mail: ginakong@khu.ac.kr)

${ }^{2}$ Corresponding author, Ph.D. Student, Department of British-American Literature \& Culture, Kyung Hee University, 1732, Deogyeong-daero, Giheung-gu, Yongin-si, Gyeonggi-do, 17104, Korea (E-mail: 01katie@naver.com)

Received: December 20, 2020 Copyright: (C) 2021 The Society for Teaching English through Media (STEM)

Revised: May 14, 2021

Accepted: May 23, 2021
} 


\section{INTRODUCTION}

The worldwide pandemic caused by the deadly virus COVID-19 has brought confusion and fatal discomfort in all areas of society, including the field of education. The Ministry of Education (2020a) in Korea announced that elementary and secondary schools would start classes online as of March 2020 due to the rapid spread of the virus in multiple Korean cities. Thus, nearly 5.4 million students in elementary and secondary school had to start their new school year online in 2020 (Statistics Korea, 2019a, 2019b, 2019c), commencing emergency remote learning (ERL). Teachers, students, employees in the field of education, and parents have been in disarray because they were not prepared for online classes (Bozkurt et al., 2020; Zhang, 2020).

Despite the unanticipated situation, the emergent remote English learning (EREL) during the pandemic revealed some positive effects; diverse learning contents for learners (Fansury, Januarty, \& Ali Wira Rahman, 2020; Kim, 2020), improvement in learners' reading skills (Kim, 2020; Y. Lee, 2020) and listening skills (Y. Lee, 2020). However, the sudden transition to EREL has raised controversial issues, such as low-quality lectures due to unprepared learning design, lack of mutual communication (Y. Lee, 2020; Park \& Chung, 2020), insufficient operation of the support system for online learning technology (Y. Lee, 2020), and unequal learning opportunities for learners (Reay, 2020).

As the spread of COVID-19 continues to intensify in Korea, learners have been attending school in different ways, such as blended, online-only, or offline classes. Thus, schools need to take active measures to meet learners' expectations in online learning and accommodate EREL more effectively and efficiently (Daniel, 2020). Hence, research on how students perceive EREL offered during the pandemic will be a valuable study to provide insights into improving the quality of online education for English learning for students in the future.

The participants for this study were middle school students because of the lack of existing studies on middle school students' perceptions on online English learning during COVID-19, whereas there are many existing studies (e.g., H. K. Jung, 2020; B. K. Lee, 2020; Park \& Chung, 2020) on elementary or college students' perceptions about online English learning during COVID-19. In addition, among secondary students in Korea, middle school students have more opportunities to be exposed to diverse learning contents compared to high school students as they study English to prepare for high-stake examinations such as the college entrance exam in Korea. Thus, research questions appropriate for middle school students were designed for this study.

Interest was used as an independent variable because of its strong relationship with the dependent variables (Tin, 2016). When learners have more interest in learning a foreign language, learners are likely to be more driven. However, interest in language learning does not rise on its own. Interest in language learning is developed when learners have positive learning experiences by interacting with other learners and making achievements through the learning process (Tin, 2016), increasing the satisfaction for the language learning experience. Interest learners have for language learning can be developed over time through active interactions and academic achievements, which can eventually guide learners towards self-directed and self-paced learning (Gyamfi \& Sukseemuang, 2018). Consequently, as interest is the fundamental element language learners need to have, it was chosen as the independent variable for this study based on the interconnectivity between interest and satisfaction, self-directed learning, achievement, and interaction in language learning.

The research questions for this study are as follows.

1. What are the secondary students' perceptions of EREL in terms of satisfaction, interest, self-directed learning, achievement, and interaction during COVID-19?

2. What are the differences in learners' perceptions of EREL in terms of self-directed learning, achievement, and interaction during COVID-19 between low and high-interest groups?

3. What advantages and drawbacks do students experience through EREL during the pandemic?

4. What improvements do students want for better EREL in the future? 


\section{LITERATURE REVIEW}

\section{Effects of Online English Learning}

With the development of information communication technology (ICT), online English learning began relatively early in the 1980s compared to other subjects (Park \& Chung, 2020). Since then, online English learning has steadily been considered a new paradigm of education by demonstrating its effectiveness in overcoming spatial limitations by broadening students' exposure (Seo \& Lee, 2020). In addition, online English learning is practical when designing a variety of learning models compared to printed materials, allowing the classes to meet students' varying needs and levels (e.g., Huang, Wu, \& Chen, 2012; Lee, 2010).

Online English learning can also provide learners with more authentic content to motivate them (Kim, 2018). The availability of authentic resources such as YouTube videos or daily news articles online enables learners to be exposed to authentic learning materials that cater to their various needs and interest (Benson, 2013). In such cases, learners find authentic learning materials more attractive because they do not highlight only certain aspects of the language that is being taught (Gilmore, 2007). Furthermore, growing interests in authentic learning materials can lead learners to take control of their learning, monitor the progress, and estimate individual learning outcomes through selfreflection on the learning process (Benson, 2013). Therefore, online English learning is particularly beneficial for learners in that online English learning can encourage them to be autonomous and study at their own pace (Koo et al., 2020).

Besides, online English learning can contribute to language learners be engaged in meaningful interaction. In particular, technology-mediated communication using synchronous computer-mediated communication (CMC) such as audio or video conferencing can offer real-time opportunities for interactions between language educators and learners (Hampel \& Stickler, 2012). In the same vein, as researchers (Ducate \& Arnold, 2011; Kitade, 2000) have pointed out, online language learning using various multimedia tools is beneficial for L2 learning due to the availability of opportunities for authentic, contextualized, and communicative interaction. According to Canto, Jauregi, and van den Bergh (2013), students could participate in collaborative work through communication using video web, facilitating active interaction among students.

Online English learning provides learners with different learning experience compared to traditional face-to-face classes. However, as shown in various previous studies, online English learning has many benefits which can offset any weaknesses online English learning may have. Thus, it can certainly ensure learners' rights to education, particularly in unprecedented times the world is experiencing with COVID-19. Thus, emergent remote English learning, also known as EREL in the current situation, has become a new paradigm of learning in a crisis (Patil, 2020).

\section{Emergency Remote Teaching and Learning}

A distinction must be made between the term online education and emergency remote teaching. The Ministry of Education (2020b) in Korea defined online education as "a mode of instruction where teaching and learning occur in different places and time" (p. 10). However, emergency remote teaching (ERT) is different in the sense that it is a type of education teachers prepare with little resources and time during a crisis (Hodges, Moore, Lockee, Trust, \& Bond, 2020); some may refer to it as ERL from the learner's perspective (Means, Bakia, \& Murphy, 2014). A clear example of ERT is the current online teaching conducted due to COVID-19. Many teachers were unprepared to teach online on such short notice (Che \& Lee, 2020; Gares, Kariuki, \& Rempel, 2020) and overwhelmed to quickly adapt to sudden policy changes about the classes (Trust \& Whalen, 2020).

The operation of online classes was an unavoidable option for education amid COVID-19, and South Korea was no exception. In such a situation, teachers had to overcome practical difficulties from using various online teaching platforms and tools to creating lesson contents using diverse media to maintain the quality of the online class $(\mathrm{H}$. K. Jung, 2020). Teachers needed to have the ability to design courses that can be effectively taught online and had to acquire skills to operate various online conferencing platforms and other technologies to teach. In addition, learners had to learn to cope with technologies and participate in online learning (H. K. Jung, 2020) and have the motivation to actively partake in either synchronous or asynchronous courses during the pandemic. 
As a result, the current situations with ERT caused by COVID-19 resulted in a deficiency of carefully designed courses (Hodges et al., 2020), and the focus of the learning experience became the interaction between learners and contents rather than the interaction between learners and teachers (Schultz \& DeMers, 2020). Thus, ERT should be set up to provide teachers with extensive information and required techniques to deliver an effective EREL experience to learners (Bates, 2020; LaBonte, 2020). Additionally, teachers need to consider that all learners may not attend on time for synchronous classes, meaning asynchronous classes or activities might be more feasible to learners (Hodges et al., 2020). Such a learning environment may require learners to have more autonomy and a strong sense of responsibility to successfully and continuously manage online learning (Kim, 2008; Palmer \& Holt, 2010).

\section{Previous Studies}

There are quite a few studies about EREL since the COVID-19 pandemic in 2020. The studies investigated two types of perceptions of EREL. First, some studies (e.g., Chang, 2020; Che \& Lee, 2020; Oh, 2020) focused on investigating English teachers' perception of remote learning during COVID-19. Second, other studies (e.g., Choi, 2020; Kim, 2020; Park \& Chung, 2020) handled students' perceptions of EREL.

Some studies revealed positive perceptions learners have towards EREL (H. K. Jung, 2020; M. A. Jung, 2020; Kim, 2020; Park \& Chung, 2020). H. K. Jung's study (2020) showed that the college EFL learners responded that the online classes covered an appropriate amount of content, and the complexity of content was moderate, such aspects of online classes during the pandemic led them to be more motivated to engage in self-directed learning during the remote learning. In the same vein, Y. Lee's study (2020) discovered that college EFL learners could learn at their own pace through the repetitive learning system online, and EREL also enabled learners to access learning materials they could repeatedly review at anytime and anywhere (Park \& Chung, 2020).

Another study by Choi (2020) showed that the perception of $3^{\text {rd }}$ and $4^{\text {th }}$ grade elementary students as well as their parents on EREL. This study found that students and parents were both more satisfied with synchronous classes. Parents pointed out the instructor's abilities to operate the classes, the level of interest for learning contents, and assignments and feedback. As elementary students are not autonomous learners, the learner-teacher interaction was the key to the success of the online classes during the pandemic. Both students and parents responded that they had more opportunities to interact with the teacher through synchronous classes, indicating that teachers need to design the classes more carefully to provide a more effective learning experience.

Despite the positive aspects of EREL, controversial issues still exist regarding the hardships and inconvenience of online teaching and learning. Learners expressed insufficient interaction time with their peers and teachers $(\mathrm{B} . \mathrm{K}$. Lee, 2020; Oh, 2020; Park \& Chung, 2020). Learners had limited chances for language learning as they could not receive immediate feedback from teachers during online classes due to the lack of interaction (Oh, 2020). In addition, learners complained of technical problems as the biggest drawback of online classes (B. K. Lee, 2020) and stated that they needed help to skillfully manage the learning process on the online platform (Park \& Chung, 2020). Moreover, learners also felt insecure about participating in the real-time lectures and frustrated with computer and network servers' instability while using programs at which they were unskilled (Park, 2020).

Some studies examined the teachers' perceptions of online English classes during COVID-19. Teachers responded that incorporating various activities during online classes was challenging (Oh, 2020). Teachers also reported that they lacked knowledge of using electronic devices and various online platforms for classes (Che \& Lee, 2020; Oh, 2020). Thus, teachers added that they spent more time simply managing the learning management system (LMS) instead of interacting with students or preparing for classes. Some feasible solutions were presented in Oh's study (2020): supplementing the learning management system and appropriately combining interactive and face-to-face classes. The study also proposed that the Ministry of Education (2020b) should offer ICT skills education for teachers.

Educational technology will continue to expand in the future, particularly during this era of the worldwide pandemic. Studies revealed the advantages and disadvantages of online English learning from different levels of learners, but the research on EREL due to COVID-19 is limited to primary and higher education institutions as of now. In other words, studies about secondary students' perceptions are still lacking. Therefore, it is pertinent to take a closer look at how secondary students perceive EREL currently being conducted amid COVID-19 to actively discuss the changing paradigm of English education. 


\section{METHOD}

\section{Participants}

263 middle school students in Gyeonggi $(n=163)$ and Seoul $(n=100)$ area participated in this study. Students were from 5 different schools: 3 schools in Gyeonggi province and 2 schools in Seoul. There are 161 female participants (61.2\%) and 102 male participants (38.8\%). The distribution of grades among participants is as follows: 148 students in Grade 1 in middle school (56.3\%), 75 students in Grade 2 in middle school (28.5\%), and 40 students in Grade 3 in middle school $(15.2 \%)^{1}$. Participants for this study had to engage in EREL during this pandemic. All 263 participants experienced asynchronous English classes during the pandemic, and only 166 participants experienced synchronous English classes. Although 97 out of 263 participants did not have synchronous classes in EREL during the pandemic, their data was still considered valid for this study because the participants had diverse learning experiences using various online learning devices such as laptops, smartphones, tablet PCs, or desktop PCs. Zoom $^{2}$, Google Meet $^{3}$, Microsoft Teams ${ }^{4}, \mathrm{EBS}^{5}$, and other school-designated platforms were used for both synchronous and asynchronous types of classes. The different learning experiences participants had during the pandemic provided diverse perceptions about EREL.

\section{Instruments and Data Collection}

Survey responses collected from 263 participants were analyzed for the study. The researchers for this study modified the survey based on previous studies (e.g., H. K. Jung, 2020; B. K. Lee, 2020; Park \& Chung, 2020) because no previous study examined middle school English learners' perceptions of EREL during COVID-19. The survey developed for this study is shown in Appendix. The research instrument used a 5-point Likert scale for the survey. The survey's main categories were as follows: satisfaction, interest, self-directed learning, achievement, and interaction. The survey consisted of 20 questions in total. Categories of satisfaction, self-directed learning, and interaction had four questions, whereas the category of interest had five and achievement three. Six short-answer questions were added at the end of the questionnaire, and they examined the advantages and disadvantages of EREL and suggestions for the future of EREL.

Since the researchers drew up the survey used for this study, a reliability check was needed. The reliability test was conducted on 20 students from a middle school in the Gyeonggi area.

TABLE 1

Reliability Test Result

\begin{tabular}{ccccccc}
\hline & Satisfaction & Interest & Self-Directed Learning & Achievement & Interaction & Overall \\
\hline Number of Items & 4 & 5 & 4 & 3 & 4 & 20 \\
$\alpha$ & 0.845 & 0.841 & 0.833 & 0.791 & 0.946 & 0.948 \\
\hline
\end{tabular}

Table 1 shows the reliability analysis result for the survey with Cronbach's alpha coefficients. The result attests to the adequacy of the survey for this study as a reliable tool (e.g., Bland \& Altman, 1997; DeVellis, 2003; Nunally \& Bernstein, 1994).

After the reliability check, this survey was conducted for two weeks, from November 22, 2020, to December 6 , 2020. The researchers informed English teachers to explain the purpose of the survey first and how to answer the questionnaire and short-answer questions in case students were unfamiliar with how to answer such questions.

\footnotetext{
${ }^{1}$ Grade 1 in middle school refers to $7^{\text {th }}$-grade, Grade 2 in middle school to $8^{\text {th }}$-grade, and Grade 3 in middle school to $9^{\text {th }}$-grade.

${ }^{2}$ Zoom (n.d.): a cloud platform accessible on mobile devices, desktops, and telephones for videoconferencing, voice conferencing, screen sharing, and real-time chat

${ }^{3}$ Google Meet (n.d.): a secure online conferencing platform by Google which allows users to do video conferencing, voice conferencing, screen sharing, and conducting large-scale meetings (over 250 people)

${ }^{4}$ Teams (Microsoft Office, 2021): an online conferencing platform by Microsoft which allows users to meet, chat, call, and collaborate real-time

${ }^{5}$ EBS (EBS Vision, n.d.): "provides top-notch programs for children and high-quality documentaries for all age group $\cdots$ complements public education ' functions as a driving force for enhance equality in education"
} 
English teachers followed the directions from the researchers, were asked to complete the survey and handed it in at the end of the designated English class.

\section{Data Analysis}

\section{1) Learners' Perceptions Towards EREL}

The collected data was analyzed using IBM SPSS Version 25. The descriptive analysis was conducted to determine the mean $(M)$ and the standard deviation $(S D)$ for the questionnaire to discover the perceptions learners have about EREL. The survey was developed based on the 5-point Likert scale $(1=$ Strongly Disagree, $2=$ Disagree, $3=$ Neutral, 4 = Agree, 5 = Strongly Agree) and was designed with five categories (satisfaction, interest, self-directed learning, achievement, and interaction). Each category was analyzed separately through the descriptive analysis. The descriptive analysis was used to show the general overview of the data in second language research (Mackey \& Gass, 2015).

Based on the descriptive statistics, independent $t$-tests were conducted using the category of interest as an independent variable and the other four categories (satisfaction, self-directed learning, achievement, and interaction) as dependent variables to investigate whether there is a statistical significance in the differences. In other words, the participants were grouped into low- and high-interest groups based on the mean in order to perform $t$-tests on four dependent variables.

\section{2) Advantages, Drawbacks, and Improvements for EREL}

Three open-ended questions were asked to gather various responses concerning the advantages, drawbacks, and improvements for EREL. The frequency analysis of recurring issues was conducted for a simple data presentation in the order of the most frequently appeared response to the least. The frequency analysis plays a significant role in statistics as it counts the number of occurrences and reports the percentiles and tendency.

\section{3) Credibility Check}

To increase the credibility of the analysis of short answers, two experts with proper qualifications in English education were asked to analyze the data with the researchers. Both experts have more than 10 years of teaching experience and have previously analyzed qualitative data in other studies. Unclear answers were excluded from the analysis of an agreement from both the experts and the researchers.

\section{RESULT}

\section{Learners' Perceptions of EREL}

\section{1) Results of Descriptive Statistics}

The descriptive analysis result for the items in the category of satisfaction for EREL is shown in Table 1. The rating scale ranged from 1 (Strongly Disagree) to 5 (Strongly Agree), and the numbers are rounded to the nearest hundredths from Table 2 to Table 6.

According to Table 2, participants were generally satisfied with EREL. Participants showed the highest satisfaction level for the coverage of learning contents in EREL $(M=3.93)$. Participants were also genuinely satisfied with the quality of EREL $(M=3.73)$. Regarding the appropriateness of the amount of time used for EREL and the amount of assignment, the latter showed a lower satisfaction level $(M=3.37)$ than the former $(M=3.59)$.

The data analysis result for the items in the category of interest for EREL is shown in Table 3 below. 
TABLE 2

Descriptive Statistics of the Category of Satisfaction

\begin{tabular}{clcc}
\hline No. & \multicolumn{1}{c}{ Items } & $M$ & $S D$ \\
\hline 1 & Quality of EREL & 3.73 & 0.87 \\
2 & Appropriateness of the amount of time used for EREL & 3.59 & 0.99 \\
3 & Appropriateness of the amount of assignment & 3.37 & 1.12 \\
4 & Sufficient coverage of learning contents through EREL & 3.93 & 0.84 \\
\hline
\end{tabular}

TABLE 3

Descriptive Statistics of Items in the Category of Interest

\begin{tabular}{clcc}
\hline No. & & \multicolumn{1}{c}{ Items } & $M D$ \\
\hline 1 & More interesting than learning English offline & 3.31 & 1.08 \\
2 & Increase in interest for EREL with the use of multimedia contents & 3.32 & 3.30 \\
3 & Inclusion of diverse contents & 1.02 & 3.00 \\
4 & Enjoyable activities (e.g., pair work, group work, etc.) & 1.16 & 2.81 \\
5 & Increase in the level of concentration compared to learning English offline & 1.25 \\
\hline
\end{tabular}

Table 3 shows that participants were moderately interested in EREL. A slight increase in participants' interest in EREL was found with the use of multimedia contents in a classroom $(M=3.32)$, which was followed by the item of EREL classes being more attractive than offline classes $(M=3.31)$ and the inclusion of diverse contents in EREL $(M$ =3.30). As for having enjoyable activities in EREL, the mean was 3.00, which means participants considered in-class activities in EREL to be neither enjoyable nor unenjoyable. The last item in this category dealt with an increase in concentration level compared to learning English offline. Unlike the other four items, this item score below the median (3.00) of the Likert-scale for this survey, which can be interpreted that participants did not feel that EREL boosted their concentration compared to learning English offline $(M=2.81)$.

The data analysis result for the items in the category of self-directed learning for EREL is shown in Table 4 below.

TABLE 4

Descriptive Statistics of the Category of Self-Directed Learning

\begin{tabular}{clcc}
\hline No. & \multicolumn{1}{c}{ Items } & $M$ & $S D$ \\
\hline 1 & Attainment of the ability for self-directed learning & 2.91 & 1.14 \\
2 & More motivation than learning English offline & 2.90 & 1.12 \\
3 & Learning at learner's own pace & 3.44 & 1.11 \\
4 & Helpful for time management for learning & 3.29 & 1.10 \\
\hline
\end{tabular}

Table 4 reveals that participants showed positive agreement for items three and four that EREL allows them to learn at their own learning pace $(M=3.44)$ and helps time management for learning $(M=3.29)$. However, participants faintly felt that EREL helped them attain self-directed learning $(M=2.91)$ or aroused more motivation from them compared to learning English offline $(M=2.90)$.

The data analysis result for the items in the category of achievement for EREL is shown in Table 5 below.

TABLE 5

Descriptive Statistics of the Category of Achievement

\begin{tabular}{clc}
\hline No. & \multicolumn{1}{c}{ Items } & $M D$ \\
\hline 1 & Enhancement of ability to study English using mobile devices & 3.38 \\
2 & Helpful in preparing for school exams or performance assessments & 1.12 \\
3 & Helpful in gaining confidence in English & 1.14 \\
\hline
\end{tabular}

As shown in Table 5, participants answered that EREL allowed them to improve their ability to study English using mobile devices such as smartphones, tablet PC, and so on $(M=3.38)$. They also agreed that EREL moderately helped them prepare for school exams and performance exams $(M=3.22)$. However, participants scored relatively low for the item that asked if EREL helped them gain confidence in using English $(M=2.95)$, which means the participants considered EREL to be relatively not helpful in gaining confidence.

The data analysis result for the items in the category of interaction with peers and teachers for EREL is shown in Table 6 below. 
TABLE 6

Descriptive Statistics of the Category of Interaction With the Peer and Teachers

\begin{tabular}{clccc}
\hline No. & & Items & $M$ & $S D$ \\
\hline 1 & Active interactions with the teacher & 3.41 & 1.10 \\
2 & Active interactions with peers & 3.29 & 1.10 \\
3 & Effective delivery of learning content & 3.57 & 1.00 \\
4 & Quick feedback from the teacher & 3.52 & 1.03 \\
\hline
\end{tabular}

In the category of interaction with peers and teachers, participants showed meaningfully high mean in the items that discuss interactions with the teacher. Participants scored the mean of 3.57, the highest in the category, for the effective delivery of learning content in class. It was followed by quick feedback from teachers $(M=3.52)$ and active interactions with the teacher $(M=3.41)$. Participants expressed through the answers they had relatively dynamic relationships with their teachers during EREL. The interaction with peer item scored the lowest mean in this category $(M=3.29)$, but it was still showed that participants had a fairly high level of interaction with their peers.

\section{2) Differences in Perceptions Depending on the Level of Interest}

The independent sample $t$-test was conducted to see if there is a statistical difference between groups. The independent sample $t$-test conducted to investigate differences between different grades was found to have no statistically significant difference. In addition, the distribution of the three grades were imbalance, so the results of the $t$-test would not be as significant as using the level of interest to see the differences among the four variables. Therefore, the level of interest was divided into the low-interest $(n=128)$ and high-interest groups $(n=135)$ to examine the differences in terms of satisfaction, self-directed learning, achievement, and interaction. As Table 7 shows below, there are differences in the low-interest group and high-interest group in all categories. Depending on the level of interest, the high-interest group shows statistically significant differences in self-directed learning, achievement, and interaction. However, although statistically significant differences were observed in all four variables, it appears that the low-interest group was also satisfied in EREL as its mean score was higher $(M=3.29)$ compared to those in other variables.

TABLE 7

Learners' Perspective Depending on the Level of Interest

\begin{tabular}{|c|c|c|c|c|c|c|c|}
\hline Item & Interest & $M$ & $S D$ & $M D$ & $d f$ & $t$ & Sig. \\
\hline Satisfaction & $\begin{array}{l}\text { Low } \\
\text { High }\end{array}$ & $\begin{array}{l}3.29 \\
4.01 \\
\end{array}$ & $\begin{array}{l}.691 \\
.639 \\
\end{array}$ & .72 & 256.513 & -8.763 & .000 \\
\hline Self-Directed Learning & $\begin{array}{l}\text { Low } \\
\text { High }\end{array}$ & $\begin{array}{l}2.55 \\
3.69 \\
\end{array}$ & $\begin{array}{l}.710 \\
.765 \\
\end{array}$ & -1.140 & 260.884 & -12.526 & .000 \\
\hline Achievement & $\begin{array}{l}\text { Low } \\
\text { High }\end{array}$ & $\begin{array}{l}2.56 \\
3.78 \\
\end{array}$ & $\begin{array}{l}.789 \\
.697 \\
\end{array}$ & -1.215 & 253.091 & -13.212 & .000 \\
\hline Interaction & $\begin{array}{l}\text { Low } \\
\text { High }\end{array}$ & $\begin{array}{l}2.87 \\
3.99 \\
\end{array}$ & $\begin{array}{l}.759 \\
.669 \\
\end{array}$ & -1.114 & 253.006 & -12.600 & .000 \\
\hline
\end{tabular}

\section{Advantages and Disadvantages of EREL}

Open-ended questions from this survey were analyzed through open-coding. Open-coding results were confirmed by two experts in the field, as mentioned earlier in the method section.

\section{1) Advantages of EREL}

The participants responded with various advantages for this open-ended question. All the answers were coded into 11 categories. The percentages are rounded to the nearest tenths. 
TABLE 8

Analysis Results of Advantages of EREL

\begin{tabular}{|c|c|}
\hline Responses & $n(\%)$ \\
\hline Convenience & $112(31.0)$ \\
\hline No Space or Time Constraints & $72(20.0)$ \\
\hline Possibility for Repeated Learning & $59(16.3)$ \\
\hline Improvement in Self-Directed Learning Ability & $45(12.5)$ \\
\hline Safety (Prevention of the Coronavirus) & $22(6.1)$ \\
\hline Improvement in Concentration & $18(5.0)$ \\
\hline Increase in Interaction & $9(2.5)$ \\
\hline Adequate Amount of Learning & $8(2.2)$ \\
\hline Increase in Interest & $7(1.9)$ \\
\hline Better Comprehension & $5(1.4)$ \\
\hline Improvement in English Skills & $4(1.1)$ \\
\hline Total & $361(100.0)$ \\
\hline
\end{tabular}

First, nearly half of the responses for this question mentioned that EREL during the pandemic has been convenient ( $n=112,31.0 \%$ ), which was followed by having no space or time constraints $(n=72,20.0 \%) .16 .3 \%(n=59)$ of responses mentioned the possibility of repeated learning as a benefit of EREL. Despite the low mean shown in the descriptive analysis, the improvement of self-directed learning ability $(n=45,12.5 \%)$ ranked fourth in the advantages of EREL. As this survey was conducted during the pandemic due to COVID-19, participants listed being safe from the coronavirus as one of the advantages of EREL during this era. Another category that scored low for the mean in the descriptive statistics was the improvement of concentration compared to learning English offline $(n=18,5.0 \%)$. Other advantages merely mentioned by participants were as follows; increase in interaction, an adequate amount of learning, increase in interest, better understanding, and improvement in English skills.

\section{2) Disadvantages of EREL}

The participants answered with similar disadvantages for this open-ended question. All the answers were coded into 11 categories. The percentages are rounded to the nearest tenths.

TABLE 9

Analysis Results of Disadvantages of EREL

\begin{tabular}{lcc}
\hline & Responses & $n(\%)$ \\
\hline Low Level of Concentration & & $137(35.8)$ \\
Low Interest & & $84(22.0)$ \\
Absence of Interaction & & $54(14.1)$ \\
Technical Difficulty & & $29(7.6)$ \\
Low Comprehension & $24(6.3)$ \\
Poor Quality of Lesson & $22(5.7)$ \\
Low of Self-Directed Learning Ability & & $17(4.4)$ \\
Inappropriate Amount of Assignments & & $12(3.1)$ \\
Increase in Fatigue & Total & $4(1.0)$ \\
\hline
\end{tabular}

With regards to disadvantages towards EREL, the three most frequent responses for this question are as follows: low level of concentration $(n=137,35.8 \%)$, low interest $(n=84,22.0 \%)$, and absence of interaction $(n=54,14.1 \%)$. Participants also mentioned technical difficulty quite frequently in the responses $(n=29,7.6 \%)$. Other less frequently answered responses include low comprehensibility $(n=24,6.3 \%)$ and poor-quality lessons $(n=22,5.7 \%)$. The least frequently appeared responses included the low self-directed learning ability, inappropriate number of assignments, and increase in fatigue due to overuse of electronics for EREL.

\section{Suggested Improvements for EREL in the Future}

Participants stated many improvements they wish to see in EREL in the future. Their responses were coded into five categories. 
TABLE 10

Analysis Results of Improvements for EREL

\begin{tabular}{lcc}
\hline & Responses & $n(\%)$ \\
\hline Quality of EREL & & $93(38.4)$ \\
Technical Difficulty & & $56(23.1)$ \\
Decrease in the Amount of Assignment & & $44(18.2)$ \\
Students-to-Teachers Interaction & & $26(10.8)$ \\
Appropriate Amount of Time for Learning & & $18(7.4)$ \\
Peer-to-Peer Interaction & & $5(2.1)$ \\
\hline & Total & $242(100.0)$ \\
\hline
\end{tabular}

Participants suggested various areas that need improvements in EREL. The most frequently mentioned category was the quality of EREL ( $n=93,38.4 \%)$. Some of the answers included that EREL should include more various contents and good quality contents, use different modes of learning (e.g., other software or application), and incorporate diverse teaching methods to increase students' concentration. The second most mentioned response was technical difficulty $(n=56,23.1 \%)$. Participants experienced difficulties in figuring out how to use the technology to partake in EREL and technical problems caused by teachers during the class.

The third most frequently shown response was the decrease in the amount of assignment $(n=44,18.2 \%)$. Participants commented that an excessive amount of assignments is given online because of the difficulties of delivering all the learning material through the online platform and the difficulties of giving assignments for performance assessment purposes during EREL.

The previous response was followed by interaction among peers and between students and teachers. Participants responded that they had less chance to interact with teachers during EREL than learning English offline. In that notion, participants wish for more opportunities to interact with teachers during EREL in the future $(n=26,10.8 \%)$. Furthermore, participants responded that EREL should incorporate more group work or pair work to interact with their peers more $(n=5,2.1 \%)$. Lastly, participants pointed out that the time spent on EREL was inappropriate $(n=$ $18,7.4 \%$ ). Some participants responded that the hours for EREL should be increased, whereas some responded the hours for EREL should be decreased. Participants wished for the adjustment in the time for EREL.

\section{DISCUSSION AND CONCLUSION}

The analysis of the collected survey data revealed that participants were moderately interested in EREL. Participants answered that EREL effectively delivered the learning content through various online platforms. However, participants showed a lower level of agreement that EREL increased their level of concentration for learning, which is in line with the findings from the open-ended questions in this study; 137 responses (35.8\%) reported the low level of concentration as a disadvantage of EREL and only 18 responses $(5.0 \%)$ reported the improvement of concentration as an advantage of EREL. Learners may have experienced a hard time concentrating because classes designed for EREL are less carefully planned than the traditional class planning (Hodges et al., 2020).

In addition, the results of the descriptive analysis showed that participants were generally satisfied with EREL. In EREL, the web worked as a means to expose them to abundant materials (Ahn, 2013) and authentic materials (Kim, 2018). Therefore, specifically, participants responded that they were satisfied with EREL because a sufficient amount of learning material was covered, which is in line with H. K. Jung's study (2020).

Although online learning should allow learners to build their knowledge individually while exploring learning materials, monitor, reflect on their learning, and even self-evaluate it (McLoughlin \& Lee, 2010; Sun, Tsai, Finger, Chen, \& Yeh, 2008; White, 2003), only $12.5 \%$ of responses reported the improvement of self-directed learning ability as an advantage of EREL. However, participants responded that they still benefited from the self-paced learning and flexible time management from EREL, which was also found in Y. Lee's study (2020).

As learners had to utilize electronic devices to participate in EREL, participants responded their ability to study using electronic devices was enhanced. As Voogt and Pareja Roblin (2012) commented, ICT skills are essential elements in 21 st century frameworks. In addition, communication and collaboration skills are considered as the basis 
that students should cultivate with the developments of language skills. Thus, online English learning should not only allow learners to develop technological skills, but also develop their digital communication skills by experiencing various forms of online learning platforms.

In terms of the category of interaction, this study revealed a higher level of learner-teacher interaction compared to the interaction among peers based on the descriptive analysis. However, the short-answer questions demonstrated that participants did not have active interaction with teachers in the classroom. The results showed that participants who responded that the learner-teacher interaction was lacking were those who did not have synchronous classes. This result is in line with Choi's study (2020), as the participants from that study responded that synchronous classes offered more chances for learner-teacher interactions. Previous studies showed a lack of interaction between peers and teachers (B. K. Lee, 2020; Park \& Chung, 2020). This study also revealed that most participants responded that peer interaction was deficient, whereas only some participants who did not experience synchronous classes answered that they wished more interaction with teachers.

In addition to the descriptive analysis, the independent samples $t$-test showed a statistically significant difference in satisfaction, self-directed learning, achievement, and interaction between the low-interest group and the highinterest group. In categories of self-directed learning, achievement, and interaction, the low-interest group and highinterest group showed negative (below 3.0 in the Likert scale) and positive (above 3.0 in the Likert scale) perceptions, respectively. Thus, the mean differences were significant. Although both groups showed positive perceptions towards satisfaction of EREL, there was still a significant mean difference between the two groups, which can be explained by a strong relationship interest has with satisfaction (Choi, Park, Choi, \& Jo, 2019).

Interest was chosen as the independent variable because it has strong correlations with the dependent variables. Interest in language learning can have a substantial impact on the learning process because it motivates learners more and makes them study harder (Dörnyei, 1990), which can lead to more effective self-directed learning as they are given opportunities to self-pace the learning process and to enhance their autonomy in learning (Gyamfi \& Sukseemuang, 2018). Learners need a sense of responsibility and a high participation rate for their learning to complete the learning process (Kim, 2018; Palmer \& Holt, 2010). In addition, when the interaction level is increased, learners are more motivated to participate in the learning process more, which can also improve their academic achievement in return (Cheng, Paré, Collimore, \& Joordens, 2011; Zheng \& Warschauer, 2015). As shown through the previous studies regarding learners' interest, satisfaction, self-directed learning, achievement, and interaction in language learning, these variables rather have cyclical effects because they are so closely related to one another.

Based on the results of this study, several implications for the future of EREL can be made. First, EREL should incorporate diverse and interactive activities for learners, as interacting with peers through collaborative learning is essential in student engagement (Cabrera et al., 2002). The use of authentic language through interactions can also increase learners' confidence in the language being learned (Wu, Yen, \& Marek, 2011). Participants added in their responses that most classes were conducted on lectures unilaterally rather than implementing collaborative learning methods such as pair or group activities. For learners' concentration for classes to be enhanced, more peer interaction should be incorporated while using many collaborating learning techniques. For example, one student wrote in the short answer section that teachers should utilize the small group rooms in Zoom to partake in discussions. Teachers unilaterally teach via Zoom or other online conferencing platforms but rarely use the small group room function to divide them into groups in the online environment and have them discuss. The student commented that discussion sessions could allow students to interact with each other and even practice English if the instruction for the discussion says that students must converse in English.

Second, the general quality of the classes should be improved for learners to have higher motivation and interest in the classes. As Hayikaleng, Nair, and Krishnasamy (2016) stated, motivation is considered a significant element in making learners succeed in their English learning. Furthermore, motivation and education achievements are positively correlated with learners' levels (Tambunan \& Siregar, 2016). Therefore, teachers should make careful efforts to make interesting and attractive materials to draw learners' attention as participants mentioned that the use of learning materials during EREL was limited to textbooks or e-textbooks. The analysis results showed that teachers utilized various multimedia content such as YouTube videos or content provided by the textbook publishers. Nevertheless, the participants responded the general quality of the classes should be enhanced for them to be more engaged in the classes. 
However, teachers, unfortunately, had less time to prepare for well-organized classes due to the sudden changes in the education system through the pandemic (Che \& Lee, 2020). In the future, teachers need to design and implement learner-centered activities for learners to manage their learning process and more actively participate in online learning during the pandemic (Koo et al., 2020), instead of merely introducing diverse multimedia contents in the classroom. To increase learner participation in online courses, teachers need to have a thorough understanding of their students (Choi, 2020). As studies (e.g., Che \& Lee, 2020; Oh, 2020) showed that teachers experienced difficulties in using the online platforms for classes, which explains why they could not incorporate various types of activities. Thus, if teachers can receive training to become more familiar with online platforms and how to operate them, the types of activities teachers can include in the classes may increase.

Third, some participants commented that most of the assignments were given during offline classes due to the limitation online classes have about giving assignments and properly assessing them. A study discovered difficulties in online assessment (Liang \& Kim, 2004) because online teaching and learning involve a more meticulous assessment approach as the interaction, communication, and learning experience are different from traditional teaching and learning (Robles \& Braathen, 2002). Thus, assignments appropriately designed for online assessment should be developed not to burden learners during offline classes. In that notion, teachers should also create a more appropriate assessment technique for EREL.

Lastly, many participants mentioned technical difficulties caused by the software, application, and sometimes teachers. For example, technical support is not always available during EREL, and learners experience difficulties in language learning through technology. Such experiences make learners feel anxious and cognitively disoriented about the learning process (Zinan \& Sai, 2017). In addition, teachers' limited knowledge of using technology can also be an obstacle to students' English language learning (Hu \& McGrath, 2011). Thus, school-designated software or applications and electronic devices used for EREL should be maintained at all times for classes to function without technical constraints. Also, training sessions should be prepared for teachers who experience difficulties using various technological tools for EREL. In addition, detailed guidelines for using different software or application should also be provided for students.

As participants stated, safety is one of the advantages of EREL concerning the current situation with the pandemic. Thus, online learning is acknowledged as an important alternative educational system in a crisis (Duncan \& Barnett, 2009), or one may say that it is the only viable option to provide education for learners. However, the education system in Korea has not completely evolved from the traditional teaching methods, even when classes went fully online during the pandemic. As Zhao (2020) describes in detail, the education system remained the same throughout the pandemic despite the changes in teaching modes, which has not benefitted the learners well. Therefore, teachers, employees, and researchers in the field of education should put their minds together to redesign the future of EREL as the situation with COVID-19 may persist for a more extended period than we expected.

Despite such vital implications this study made, this study has some limitations. First, since the participants were only from Seoul and Gyeonggi-do area, the results cannot be generalized to the entire middle school students in Korea as students may have different experiences with EREL. For further research, a larger population from across the nation may be needed. Secondly, if more data are collected through methods such as interviews, more comprehensive and in-depth results may be drawn from the study.

\section{REFERENCES}

Ahn, D. H. (2013). ICT and English education in the global age. The Korean Association of General Education, 7(4), 501-527.

Bates, T. (2020, March 9). Advice to those about to teach online because of the coronavirus. Retrieved from https://www.tonybates.ca/2020/03/09/advice-to-those-about-to-teach-online-because-of-the-corona-virus/

Benson, P. (2013). Drifting in and out of view: Autonomy and the social individual. In P. Benson \& L. Cooker (Eds.), The applied linguistic individual: Sociocultural approaches to identity, agency, and autonomy (pp. 75-89). Sheffield, UK: Equinox. 
Bland, J., \& Altman, D. (1997). Statistics notes: Cronbach's alpha. BMJ, 374(7080), 572. https://doi.org/10.1136/bmj.314.7080.572

Bozkurt et al. (2020). A global outlook to the interruption of education due to COVID-19 Pandemic: Navigating in a time of uncertainty and crisis. Asian Journal of Distance Education, 15(1), 1-126. https://doi.org/10.5281/zenodo.3878572

Cabrera, A. F., Nora, A., Crissman, J. L., Terenzini, P. T., Bernal, E. M., \& Pascarella, E. T. (2002). Collaborative learning: Its impact on college students' development and diversity. Journal of College Student Development, 43(1), 20-34.

Canto, S., Jauregi, K., \& van den Bergh, H. (2013). Integrating cross-cultural interaction through videocommunication and virtual worlds in foreign language teaching programs: Is there an added value? ReCALL, 25(1), 105-121. https://doi.org/10.1017/S0958344012000274

Chang, Y. (2020). Teacher reflection on emergency remote teaching during the Coronavirus pandemic in a multicultural EAP classroom in South Korea. Multimedia-Assisted Language Learning, 23(3), 235-257.

Che, H., \& Lee, D. (2020). Exploring secondary teacher's experience of distance learning due to COVID-19. Journal of Learner-Centered Curriculum and Instruction, 2(16), 1047-1071. https://doi.org/10.22251/jlcci.2020.20.16.1047

Cheng, C. K., Paré, D. E., Collimore, L. M., \& Joordens, S. (2011). Assessing the effectiveness of a voluntary online discussion forum on improving students' course performance. Computers \& Education, 56(1), 253-261. https://doi.org/10.1016/j.compedu.2010.07.024

Choi, M., Park, D., Choi, G., \& Jo, H. (2019). The study on satisfaction in English learning depending on motivation types of students majoring in physical education: The mediating effects of the interest, participation and confidence in English learning. Korean Association for Learner-Centered Curriculum \& Instruction, 19(12), 835-857. https://doi.org/10.22251/jlcci.2019.19.12.859

Choi, W. (2020). A survey on the elementary school students' and parents' perceptions toward online English classes in the COVID-19 pandemic: A comparison between synchronous and asynchronous classes. Primary English Education, 26(4), 115-135. https://doi.org/10.25231/pee.2020.26.4.115

Daniel, S. J. (2020). Education and the COVID-19 pandemic. Prospects, 49, 91-96. https://doi.org/10.1007/s11125020-09464-3

DeVellis, R. (2003). Scale development: Theory and applications. Los Angeles, CA: Sage.

Dörnyei, Z. (1990, April). Analysis of motivation components in foreign language learning. Paper presented at the 1990 World Congress of Applied Linguistics, Thessalonikia-Halkidiki, Greece.

Ducate, L., \& Arnold, N. (2011). Technology, CALL and the Net Generation: Where are we headed from here? In N. Arnold \& L. Ducate (Eds.), Present and future promises of CALL: From theory and research to new directions in language teaching (pp. 1-22). San Marcos, TX: CALICO.

Duncan, H., \& Barnett, J. (2009). Learning to teach online: What works for pre-service teachers. Journal of Educational Computing Research, 40(3), 357-376. https://doi.org/10.2190/EC.40.3.f

EBS Vision. (n.d.). Retrieved from https://global.ebs.co.kr/global/introduction/vision

Fansury, A. H., Januarty, R., \& Ali Wira Rahman, S. (2020). Digital content for millennial generations: Teaching the English foreign language learner on COVID-19 pandemic. Journal of Southwest Jiaotong University, 55(3), 1-12. https://doi.org/10.35741/issn.0258-2724.55.3.40

Gares, S. L., Kariuki, J. K., \& Rempel, B. P. (2020). Community matters: Student-instructor relationships foster student motivation and engagement in an emergency remote teaching environment. Journal of Chemical Education, 97(9), 3332-3335. https://doi.org/10.1021/acs.jchemed.0c00635

Gilmore, A. (2007). Authentic materials and authenticity in foreign language learning. Language Teaching, 40, 97118. https://doi.org/10.1017/S0261444807004144

Google Meet. (n.d.). Retrieved from https://apps.google.com/intl/ko/meet/

Gyamfi, G., \& Sukseemuang, P. (2018). EFL learners' satisfaction with the online learning program, Tell Me More. Turkish Online Journal of Distance Education, 19(1), 183-202. https://doi.org/10.17718/tojde.382798

Hampel, R., \& Stickler, U. (2012). The use of videoconferencing to support multimodal interaction in an online language classroom. ReCALL, 24(2), 116-137. https://doi.org/10.1017/S095834401200002X 
Hayikaleng, N., Nair, S. M., \& Krishnasamy, H. N. (2016). Thai students' motivation on English reading comprehension. International Journal of Education and Research, 4(6), 477-486.

Hodges, C., Moore, S., Lockee, B., Trust, T., \& Bond, A. (2020). The difference between emergency remote teaching and online learning. Educause Review. Retrieved from https://er.educause.edu/articles/2020/3/thedifference-between-emergency-remote-teaching-and-online-learning

Hu, Z., \& McGrath, I. (2011). Innovation in higher education in China: Are teachers ready to integrate ICT in English language teaching? Technology, Pedagogy and Education, 20(1), 41-59. https://doi.org/10.1080/1475939X.2011.554014

Huang, H.-W., Wu, C.-W., \& Chen, N.-S. (2012). The effectiveness of using procedural scaffoldings in a paper plussmartphone collaborative learning context. Computers \& Education, 59(2), 250-259. https://doi.org/10.1016/j.compedu.2012.01.015

Jung, H. K. (2020). College students' satisfaction with the overall implementation of online classes and testing during the Corona 19 pandemic. Multimedia-Assisted Language Learning, 23(3), 392-412. https://doi.org/10.1177/030216373900700406

Jung, M. A. (2020). The structural relationship among English online activities, self-directedness, attitudes toward international community and English proficiency of Korean EFL university students. The Modern English Society of Korea, 64(2), 283-302. https://doi.org/10.17754/MESK.64.2.283

Kim, H. (2018). An analysis of achievement and teaching presence in a blended learning environment: Smart learning at an online universities. Journal of Learner-Centered Curriculum and Instruction, 18(8), 755-779. https://doi.org/10.22251/jlcci.2018.18.8.755

Kim, H. (2020). The efficacy of online lectures in university and English reading comprehension for EFL learners. The Journal of the Convergence on Culture Technology, 6(3), 225-231. https://doi.org/10.17703/JCCT.2020.6.3.225

Kim, J. (2008). E-learning and English education. Seoul: Hankook Publishing House.

Kitade, K. (2000). L2 learners' discourse and SLA theories in CMC: Collaborative interaction in Internet chat. Computer Assisted Language Learning, 13(2), 143-166. https://doi.org/10.1076/0958-8221(200004)13:2;1$\mathrm{D} ; \mathrm{FT} 143$

Koo, S., Kang, E., Kim, S., Kim, I., Ryu, K., Park, S., Lee, M., Hong, S., \& Hwang, Y. (2020). Summoned future education looking at a school in the post-corona era. Seoul: Tekville.

LaBonte, R. (2020, March 30). Emergency remote teaching: Resources, tools, and ideas. Retrieved from https://canelearn.net/emergency-remote-teaching/

Lee, B. K. (2020). A study on learners' response to online college English class as general education due to the COVID-19 pandemic. Korean Journal of General Education 14(4), 97-112. https://doi.org/10.3390/nu12010197

Lee, H. J. (2010). Vygotskian sociocultural theory and technology-mediated English learning. Education Research, 47, 23-56. https://doi.org/10.17253/swueri.2010.47..002

Lee, Y. (2020). A study of using flipped learning on differentiated-level college learners' perceptions, class satisfaction, and reading and English-speaking achievement. Journal of Learner-Centered Curriculum and Instruction, 20(9), 181-206. https://doi.org/10.22251/jlcci.2020.20.9.181

Liang, X., \& Kim, C. (2004). Classroom assessment in web-based instructional environment: Instructors' experience. Practical Assessment, Research \& Evaluation, 9(7). https://doi.org/10.7275/84mr-wp41

Mackey, A., \& Gass, S. M. (2015). Second language research ( $2^{\text {nd }}$ ed.). New York, NY: Routledge.

McLoughlin, C., \& Lee, M. J. W. (2010). Personalised and self-regulated learning in the Web 2.0 era: International exemplars of innovative pedagogy using social software. Australasian Journal of Educational Technology, 26(1), 28-43. https://doi.org/10.14742/ajet.1100

Means, B., Bakia, M., \& Murphy, R. (2014). Learning online: What research tells us about whether, when and how. New York, NY: Routledge.

Microsoft Office. (2021, April 29). Microsoft Teams service description. Retrieved from https://docs.microsoft.com/en-us/office365/servicedescriptions/teams-service-description 
Ministry of Education. (2020a). All kindergarten, elementary, middle, high and special education schools nationwide have been postponed for an additional 2 weeks (COVID-19). Sejong: Ministry of Education.

Ministry of Education. (2020b). 2020 remote class operation casebook. Sejong: Ministry of Education Nunally, J. C., \& Bernstein, I. H. (1994). Psychometric theory ( $3^{\text {rd }}$ ed.). New York, NY: McGraw-Hill.

Oh, J. S. (2020). The difficulties and improvement of elementary English teacher in distance education: A qualitative analysis through in-depth interview (Unpublished master's thesis). Graduate School of Gyeongin National University of Education, Incheon, Korea.

Palmer, S., \& Holt, D. (2010). Students' perceptions of the value of the elements of an online learning environment: Looking back in moving forward. Interactive Learning Environments, 18(2), 135-151. https://doi.org/10.1080/09539960802364592

Park, E. K. (2020). Perception of learner anxiety towards online college English classes during COVID-19. Multimedia-Assisted Language Learning, 23(3), 320-338. https://doi.org/10.1365/s40112-015-0964-z

Park, H. J., \& Chung, S. J. (2020). An exploration of elementary students' level of satisfaction with online EFL instruction. Multimedia-Assisted Language Learning, 23(3), 339-358. https://doi.org/10.9773/sosei.58.187

Patil, D. P. (2020). Trends and challenges in English language teaching. Studies in Indian Place Names, 40(39), 158164.

Reay, D. (2020). English education in the time of Coronavirus. FORUM, 62(3), 311-322. https://doi.org/10.15730/forum.2020.62.3.311

Robles, M., \& Braathen, S. (2002). Online assessment techniques. The Delta Pi Epsilon Journal, 44(1), 39-49.

Schultz, R. B., \& DeMers, M. N. (2020). Transitioning from emergency remote learning to deep online learning experiences in geography education. Journal of Geography, 119(5), 142-146. https://doi.org/10.1080/00221341.2020.1813791

Seo, J. W., \& Lee, C. (2020). Action-items for training and development designers to reinforce the learners' presence in the online-based higher education environment. Journal of Learner-Centered Curriculum and Instruction, 20(8), 695-718. https://doi.org/10.22251/jlcci.2020.20.8.695

Statistics Korea. (2019a, November 12). Summary of elementary school. Retrieved from https://kosis.kr/statHtml/statHtml.do?orgId=334\&tblId=DT_1963003_002\&conn_path=I2\&language=en

Statistics Korea. (2019b, November 12). Summary of high school. Retrieved from https://kosis.kr/statHtml/statHtml.do?orgId=334\&tblId=DT_1963003_004\&conn_path=I2\&language=en

Statistics Korea. (2019c, November 12). Summary of middle school. Retrieved from https://kosis.kr/statHtml/statHtml.do?orgId=334\&tblId=DT_1963003_003\&conn_path=I2\&language=en

Sun, P. C., Tsai, R. J., Finger, G., Chen, Y.-Y., \& Yeh, D. (2008). What drives successful e-learning? An empirical investigation of the critical factors influencing learner satisfaction. Computers \& Education, 50(4), 11831202. https://doi.org/10.1016/j/compedu.2006.11.007

Tambunan, A. R. S., \& Siregar, T. M. S. (2016). Students' motivation in learning English language: A case study of electrical engineering department students. Journal of English Language Studies, 1(2), 63-70. https://doi.org/10.30870/jels.v1i2.956.g750

Tin, T. B. (2016). Stimulating student interest in language learning. London: Palgrave Macmillan. https://doi.org/101057/978-1-137-34042-9_1

Trust, T., \& Whalen, J. (2020). Should teachers be trained in emergency remote teaching? Lessons learned from the COVID-19 pandemic. Journal of Technology and Teacher Education, 28(2), 189-199.

Voogt, J., \& Pareja Roblin, N. (2012). A comparative analysis of international frameworks for 21 st century competences: Implications for national curriculum policies. Journal of Curriculum Studies, 44(3), 299-321. https://doi.org/10.1080/00220272.2012.668938

White, C. (2003). Language learning in distance education. Cambridge, MA: Cambridge University Press.

Wu, W. C. V., Yen, L. L., \& Marek, M. (2011). Using online EFL interaction to increase confidence, motivation, and ability. Journal of Educational Technology \& Society, 14(3), 118-129.

Zhang, T. (2020). Learning from the emergency remote teaching-learning in China when primary and secondary schools were disrupted by COVID-19 pandemic. Research Square. https://doi.org/10.21203/rs.3.rs-40889/v1 
Zhao, Y. (2020). Tofu is not cheese: Rethinking education amid the COVID-19 pandemic. ECNU Review of Education, 3(2), 189-203. https://doi.org/10.1177/209653110928082

Zheng, B., \& Warschauer, M. (2015). Participation, interaction, and academic achievement in an online discussion environment. Computers \& Education, 84, 78-89. https://doi.org/10.1016/j.compedu.2015.01.008

Zinan, W., \& Sai, G. T. B. (2017). Students' perceptions of their ICT-based college English course in China: Case study. Teaching English with Technology, 17(3), 53-76.

Zoom. (n.d.). Video conferencing, web conferencing, webinars, screen sharing. Retrieved from https:/explore.zoom.us/about?_ga=2.142284980.741391717.1614347215-2074499301.1595291471

\section{APPENDIX}

Survey

The aim of this survey is to figure out the middle school students' perceptions on the emergent remote English learning in 2020 due to the spread of the coronavirus this year. There is no right or wrong answer with each question, please make sure to honestly answer the questions.

In addition, please state your thoughts freely on the open-ended questions. We assure you that that all responses will not be used for any purposes other than this study. Thank you for participating in the survey.

1. Gender: Female $\square$ Male $\square$

2. Grade: $7^{\text {th }}$ Grade $\square / 8^{\text {th }}$ Grade $\square / 9^{\text {th }}$ Grade $\square$

3. Forms of Emergent Remote English Learning (Multiple choices can be selected)

(1) Synchronous classes (e.g., Zoom, Google meet, etc.) $\square$

(2) Asynchronous classes (e.g., EBS, etc.) $\square$

(3) School Designated Learning System (e.g., e-hakseupteo, etc.) $\square$

(4) Number of Sessions Per Week for Choices among (1) (3)

(e.g., 2 days of offline classes at school, 2 days of Zoom classes, 1 day of EBS, etc.)

4. Questionnaire

\begin{tabular}{|c|c|c|c|}
\hline Category & Questionnaire & $\begin{array}{l}\text { Strongly } \\
\text { Disagree }\end{array}$ & $\begin{array}{l}\text { Strongly } \\
\text { Agree }\end{array}$ \\
\hline \multirow{4}{*}{$\begin{array}{l}\text { Satisfaction in } \\
\text { EREL }\end{array}$} & The quality of EREL was satisfying. & & \\
\hline & The amount of time in EREL was appropriate. & & \\
\hline & An appropriate amount of assignment was given after EREL. & & \\
\hline & $\begin{array}{l}\text { The EREL covered sufficient amount of learning contents } \\
\text { during the semester. }\end{array}$ & & \\
\hline \multirow{5}{*}{ Interest in EREL } & EREL was more interesting than offline learning. & & \\
\hline & $\begin{array}{l}\text { The use of multimedia contents in EREL has increased the } \\
\text { interest for the class. }\end{array}$ & & \\
\hline & EREL was comprised of diverse learning contents. & & \\
\hline & $\begin{array}{l}\text { The activities utilized in EREL (e.g., pair work, group work, } \\
\text { etc.) were enjoyable. }\end{array}$ & & \\
\hline & $\begin{array}{l}\text { EREL has increased the level of concentration in comparison } \\
\text { to offline learning. }\end{array}$ & & \\
\hline \multirow{4}{*}{$\begin{array}{c}\text { Self-Directed } \\
\text { Learning towards } \\
\text { EREL }\end{array}$} & EREL helped me attain the ability for self-directed learning. & & \\
\hline & EREL motivated me more than offline classes. & & \\
\hline & $\begin{array}{l}\text { EREL allowed me to adapt the classes to my own learning } \\
\text { pace. }\end{array}$ & & \\
\hline & EREL have been helpful for time management for learning. & & \\
\hline \multirow{3}{*}{$\begin{array}{l}\text { Achievement } \\
\text { in EREL }\end{array}$} & $\begin{array}{l}\text { EREL enhanced my ability to study English using electronic } \\
\text { devices. }\end{array}$ & & \\
\hline & $\begin{array}{l}\text { EREL helped me prepare for school exams (final/midterm } \\
\text { exams) or performance assessments. }\end{array}$ & & \\
\hline & EREL helped me gain confidence in English. & & \\
\hline \multirow{4}{*}{$\begin{array}{l}\text { Interaction among } \\
\text { Peers and with } \\
\text { Teachers in EREL }\end{array}$} & EREL enabled active interactions with the teacher. & & \\
\hline & EREL enabled active interactions with peers. & & \\
\hline & EREL effectively delivered the learning content. & & \\
\hline & $\begin{array}{l}\text { EREL allowed for me to receive quick feedback from the } \\
\text { teacher }\end{array}$ & & \\
\hline
\end{tabular}


What kinds of electronic devices did you use for EREL? (e.g., laptops, desktops, tablet PCs, smartphones, etc.).

List the most frequently used learning materials in order. (e.g., textbook, e-book, materials related to EBS, handout, etc.).

Open-Ended

List the most frequently used activities in EREL in order.

Questions (e.g., one-sided lectures, pair work, group activity, presentation, etc.)

What are the advantages of EREL? (Write two or more)

What are the disadvantages of EREL? (Write two or more)

Which improvements are needed in the future to improve EREL? (Write two or more) 